\title{
Marine Organisms for the Sustainable Management of Plant Parasitic Nematodes
}

\author{
Pasqua Veronico * and Maria Teresa Melillo
}

check for

updates

Citation: Veronico, P.; Melillo, M.T. Marine Organisms for the Sustainable Management of Plant Parasitic Nematodes. Plants 2021, 10, 369. https://doi.org/10.3390/plants 10020369

Academic Editor: Suresh Awale

Received: 20 January 2021

Accepted: 9 February 2021

Published: 14 February 2021

Publisher's Note: MDPI stays neutral with regard to jurisdictional claims in published maps and institutional affiliations.

Copyright: (c) 2021 by the authors. Licensee MDPI, Basel, Switzerland. This article is an open access article distributed under the terms and conditions of the Creative Commons Attribution (CC BY) license (https:// creativecommons.org/licenses/by/ $4.0 /)$.
Institute for Sustainable Plant Protection, CNR, Via G. Amendola 122/D, 70126 Bari, Italy; mariateresa.melillo@ipsp.cnr.it

* Correspondence: pasqua.veronico@ipsp.cnr.it; Tel.: +39-0805583377
Abstract: Plant parasitic nematodes are annually responsible for the loss of $10 \%-25 \%$ of worldwide crop production, most of which is attributable to root-knot nematodes (RKNs) that infest a wide range of agricultural crops throughout the world. Current nematode control tools are not enough to ensure the effective management of these parasites, mainly due to the severe restrictions imposed on the use of chemical pesticides. Therefore, it is important to discover new potential nematicidal sources that are suitable for the development of additional safe and effective control strategies. In the last few decades, there has been an explosion of information about the use of seaweeds as plant growth stimulants and potential nematicides. Novel bioactive compounds have been isolated from marine cyanobacteria and sponges in an effort to find their application outside marine ecosystems and in the discovery of new drugs. Their potential as antihelmintics could also be exploited to find applicability against plant parasitic nematodes. The present review focuses on the activity of marine organisms on RKNs and their potential application as safe nematicidal agents.

Keywords: plant-parasitic nematodes; seaweeds; marine cyanobacteria; sponges; sustainable strategies

\section{Introduction}

Plant-parasitic nematodes (PPNs) are one of the most important agricultural pests. Thousands of crops and trees are susceptible to nematode infections, which result in 10\%-25\% global yield losses [1,2]. Most economic losses are caused by sedentary PPN genera, principally the root-knot (Meloidogyne spp.) and the cyst (Heterodera spp. and Globodera spp.) nematodes [3]. Root-knot nematodes (RKNs) constitute a major group of PPNs that are distributed worldwide. They are obligate root parasites of thousands of plant species and damage both horticultural and field crops [4]. Infection causes root galls and hinders the normal uptake of water and nutrients, resulting in poor growth, loss of quality and yield and reduced resistance to other biotic and abiotic stresses [5]. The economic impact of these parasites is expected to further increase due to global climate change and the resulting occurrence of new invasive nematode species and the emergence of virulent populations able to overcome plant resistance genes [6,7]. Control of RKNs has been achieved mainly through soil treatment with chemical nematicides, whose use has been severely restricted by recent European legislation and subsequent additions (Reg. EC $1107 / 2009 ; 459 / 2010$ and 293/2013), which focus on animal and human health as well as the environment. The total ban or restricted use of most nematicides has raised an urgent need for safe and effective control options [8], thus increasing research on sustainable alternatives such as biocontrol agents, green manures and organic amendments [9-12]. Compounds deriving from plants, microorganisms and marine organisms could ensure a virtuous combination of nematicidal efficacy and environmental safety, as their natural origin ensures their low persistence both in soil and crops and, therefore, a low impact on the environment and human and animal health [13,14]. Due to their distribution in different ecosystems and their accessibility, plants constitute a major source of specialized metabolites suitable for crop parasite and pathogen control. Much effort has been put 
into developing new bioactive agents from plants [15-17]. However, with oceans covering more than $70 \%$ of the Earth's surface, marine biodiversity may offer an alternative source of useful specialized metabolites for the control of plant, animal and human parasites and pathogens. Marine organisms have already yielded thousands of chemicals, with hundreds of new compounds still being discovered every year. These have yielded several bioactive metabolites that have been successfully developed by the pharmaceutical industry-mainly for human diseases [18-20]. However, several marine natural products abundantly present in microorganisms, algae and invertebrates can also represent a source of potentially exploitable nematicidal compounds for the formulation of new, safe nematicides. This review will focus on advances in the roles played by natural compounds from marine environments in the control of plant-parasitic nematode infestation.

\section{Seaweeds}

Algae were primarily known as growth stimulants due to their positive effects on plant photosynthetic pigments and on the content of total carbohydrates, starch, amino acids and proteins [21]. Moreover, the application of seaweed extracts can stimulate nitrogen uptake and metabolism in the treated plants [22]. The stimulatory effect of marine bioactive substances has been ascribed to the presence of phytohormones such as auxins, gibberellins and the precursor of ethylene and betaine, together with many other organic and inorganic molecules [23]. Algae synthesize unusual and complex polysaccharides such as agars, alginates, carrageenans, fucans and phlorotannins, which show a variety of biological activities and are involved in host defense mechanisms [23,24].

Interest in the application of seaweed extracts in the management of PPNs, especially of RKNs, has increased in the last decade due to the combination of their beneficial effects on plants and their activity towards several plant pathogens. Seaweed extract applications on plants result in improved crop performance and yield, early seed germination and elevated resistance to biotic and abiotic stresses [24,25]. Improvement in diving and cultivation methods, as well as in the recycling of seaweed wastes, may help to disclose the huge potential of these marine organisms for sub-tropical and tropical root-knot nematode management. Table 1 summarizes the seaweed that was exploited during in vitro and in vivo studies, as well as the details of the trial, material, dose and type of inoculum that was used.

\subsection{Seaweed's Effect on Juvenile Viability and Egg Hatching}

Egg hatching, motility and survival are critical behaviors in the RKN life cycle. Interference in any of these steps could interrupt the nematode's intact life cycle and effectively control its reproduction and ability to damage the host plant [26].

Several studies reported nematostatic and nematicidal activity of seaweed extracts, which causes inhibition of egg hatching and/or induction of second-stage juvenile (J2) mortality (Table 1). However, studies on seaweeds from phyla Phaeophyta (brown algae), Rhodophyta (red algae) and Chlorophyta (green algae) have also indicated that not all marine algae have a nematicidal activity.

The highest nematicidal potential has generally been demonstrated by species of marine brown seaweeds. In a screening of eighteen species of marine algae, Paracer et al. [27] reported that only the aqueous extract of the brown alga Spatoglossum schroederi killed J2 of Meloidogyne incognita, Meloidogyne javanica and Meloidogyne arenaria after a $24 \mathrm{~h}$ exposure to concentrations of $1.0,0.75$, and $0.50 \%$ (dry weight in aqueous solutions). They also related this nematicidal efficacy to extract acidity as larvae appeared vacuolated within $24 \mathrm{~h}$. A strong nematicidal activity against M. javanica J2 was also displayed by aqueous, ethanol and methanol extracts of the brown alga Stoechospermum polypodioides [28-31] and by the extracts of the brown seaweeds Sargassum tenerrimum, Sargassum swartzii and Sargassum wigbtii [32]. In a further in vitro study on the effect of 32 seaweeds on $M$. javanica $\mathrm{J} 2$ mortality and egg hatching, a $72 \mathrm{~h}$ exposure of J2 and eggs to water and methanol 
extracts from Phaeophyta species S. tenerrimum, Padina tetrastromatica and Melanothamnus afaqhusainii caused an almost complete J2 mortality and egg hatching suppression [33].

In general, marine brown algae always exhibit a stronger nematicidal activity against juveniles when compared with green and red seaweeds. In a comparative assay on $M$. javanica $\mathrm{J} 2$ viability and egg hatchability, extracts from brown seaweeds (S. tenerrimum, Cystoseira indica, Jolyna laminarioides, P. tetrastromatica, and Lyengaria stellata) were found to be highly active on nematode $\mathrm{J} 2$ as they caused complete mortality after a $72 \mathrm{~h}$ exposure and strongly reduced egg hatching ( $4 \%$ vs. $68 \%$ of the nontreated control) [34]. Conversely, the green algae Ulva rigida and Codium iyengarii were less effective as they caused only 30 and 35\% J2 mortality and 30 and 26\% egg hatching, respectively [34]. Similarly, 90\%-97\% mortality of $M$. incognita $\mathrm{J} 2$ occurred after a $72 \mathrm{~h}$ exposure to 2.5, 5 and $10 \%$ extracts from the brown algae Cystoseria myrica, Cystoseria trinode and Padina pavonia, whereas a lower activity (73\% mortality) was recorded for a similar treatment with the extract from the red alga Digenea simplex [35].

By contrast, ethanol extracts of the brown alga Stokeyia indica, green alga C. iyengarii and red seaweeds Jania capillacea and Solieria robusta showed similar activities on M. javanica $\mathrm{J} 2 \mathrm{~s}$ and caused more than $50 \%$ mortality rates after a $24 \mathrm{~h}$ exposure to a $10 \mathrm{mg} \mathrm{mL}^{-1}$ concentration [36]. A comparison of the effects on M. incognita J2 and eggs of aqueous extracts from the green algae Enteromorpha flexuosa, Ulva lactuca and Codium fragile, the brown algae C. myrica and Sargassum muticum and the red algae Dilsea carnosa and Laurencia nidifica showed the highest J2 mortality (86.7\%) for the extracts of C. fragile, D. carnosa $(82.9 \%)$ and C. myrica (73.3\%), whereas the lowest egg hatching percentages were recorded for egg treatment with extracts of E. flexuosa, D. carnosa and C. fragile-15.9, 20.6 and 22.7\%, respectively [37]. Finally, a comparative in vitro experiment with ethanol extracts of the red algae Corallina mediterranea and Corallina officinalis and the green alga Ulva fasciata indicated a higher effect of $U$. fasciata extract on $M$. incognita egg hatching (an 87\% egg hatching decrease after a 3-day exposure), whereas all extracts were similarly active on J2 and caused $80 \%-85 \%$ mortality rates after a $12 \mathrm{~h}$ exposure to 0.5 or $1 \mathrm{mg} \mathrm{mL}^{-1}$ concentrations [38].

In spite of the large number of studies on seaweed raw extracts, there are very few commercial formulations of these products and their effectiveness on root-knot nematodes is poorly documented. In a study on the effects of two commercial formulations of the brown algae Ascophyllum nodosum and Ecklonia maxima on the root-knot species Meloidogyne chitwoodi and Meloidogyne hapla, Ngala et al. [39] reported a significant effect on $M$. chitwoodi egg hatching and $\mathrm{J} 2$ infectivity for only the $A$. nodosum extract. It has been assumed that compounds of $A$. nodosum extract can interact with enzymes, such as lipase, proteinase and chitinase, involved in the hatching process [40].

\subsection{Seaweed Effects on Nematode Reproduction and Multiplication and Plant Growth}

Several reports have indicated that the application of seaweed extracts or biomasses to soil can result in decreased levels of nematode attack and improved plant growth (Table 1).

The first investigations of seaweed nematicidal effects in soil date back to last century and are focused mainly on the brown alga $A$. nodosum. Tarjan [41] found that the application of $A$. nodosum extracts to citrus seedlings infested by Radopholus similis caused a significant reduction in nematode density and increased plant weight when compared with nontreated plants. Likewise, commercial extracts of $A$. nodosum (Maxicrop and Sea-Born), when applied to the soil, controlled Belonolaimus longicaudatus on centipede grass [42]. Following these first reports, a number of studies demonstrated a significant suppressive effect of $A$. nodosum extracts on root-knot nematodes-mainly $M$. incognita and $M$. javanica on tomatoes [43-46]. These studies unanimously reported a reduced root-knot nematode infestation and number of eggs, as well as improved plant growth, following soil treatments with $A$. nodosum extracts. Nour El-Deen et al. [47] documented that the treatment of basil plants with the combined application of A. nodosum extract, cabbage (Brassica oleracea) leaves and arabic gum, resulted in the highest reduction of $M$. incognita galls and egg masses and in an increased plant fresh weight. Wu et al. [44] suggested that effects of 
A. nodosum extract on nematodes are at least partially due to the betaine content of the extract. In this respect, further studies by the same authors [45] indicated that betaines were absorbed by plants and stimulated an increased resistance to nematode invasion. In the same study, Arabidopsis thaliana plants grown under monoxenic conditions in the presence of an alkaline extract of $A$. nodosum or a mixture of betaines ( $\gamma$-aminobutyric acid betaine; $\delta$-aminovaleric acid betaine; glycinebetaine) exhibited a significant decrease in $M$. javanica females in plant roots and in the number of eggs recovered 45 days after inoculation. Finally, soil treatments with $A$. nodosum were also found to be effective in controlling $M$. chitwoodi infestation on tomato plants and in improving the growth of nematode-infested plants [39].

Featonby-Smith and van Staden [48] tested the effects of another brown alga, E. maxima, and reported that treatment with seaweed concentrate (Kelpak 66, Kelp Products (Pry.) Ltd., Cape Town, South Africa) reduced M. incognita galling and induced the growth of tomato roots. Although the number of nematodes increased in the soil after the application of seaweed concentrate, the numbers that had established themselves in the roots were reduced when compared with the control. Presence of cytokinins in marine algae extracts may be responsible for nematicidal activity as it has been stated that high concentrations of kinetin inhibited both larval penetration and development in the roots of tomato plants [49]. Modes of application of E. maxima seaweed concentrate (SWC) resulted in the opposite effects [50]. Foliar-applied SWC did not enhance plant growth and encouraged nematode galling, whereas a significant reduction in nematode infestation was noted when SWC was applied as a soil drench. The effectiveness of the seaweed products from E. maxima was also demonstrated by the control of M. chitwoodi and M. hapla infections on tomato plants [39].

As in the in vitro studies described above, brown algae showed a higher nematicidal effectiveness when compared with the red and green algae in in vivo experiments. Soil treatments with the aqueous extracts of the brown algae C. myrica, C. trinode and P. pavonia were found to be more effective in reducing the $M$. incognita infestation on eggplants than the extracts from the red alga $D$. simplex, the green alga $C$. serrulata and the seagrass Thalassodendron ciliatum, though the beneficial effects of all extracts were improved by their combination with chemical nematicides [35].

Soil drench treatments $(1 \mathrm{mg} / \mathrm{mL})$ with ethanolic extracts of the green alga $U$. fasciata Delile and the red algae C. officinalis and C. mediterranea significantly reduced $M$. incognita infestation on tomato plants, though the extract of $U$. fasciata was much more effective (a $77.5 \%$ reduction in gall number/root) than the C. officinalis and C. mediterranea extracts, with a 50.3 and $34.7 \%$ reduction, respectively [38,51].

As indicated by another large group of studies, an alternative option for the exploitation of seaweeds in nematode control is represented by soil amendments with raw or composted seaweed biomasses. Soil treatments with dry powder of the brown alga $J$. laminarioides and the red algae Cystoclonium purpereum and Hypnea valentiae resulted in a strong reduction of root-gall formation on okra and tomato roots infested by $M$. javanica and in improved plant growth [34]. In a study of El-Ansary and Hamouda [52], the soil application of powdered dry biomass from U. lactuca (green alga), Jania rubens and Laurencia obtuse (red seaweeds) and the brown alga Sargassum vulgare significantly decreased galls and root-knot nematode egg masses on banana (Musa spp.) roots and the nematode population in soil. The efficacy of $U$. lactuca can be explained by the high content of nematotoxic phenolics. Analogously, soil amendments with dry powder of S. tenerrimum significantly reduced root-knot nematode infestation on okra roots [32,34]. The combination of the brown seaweed Stoechospermum marginatum and biocontrol agents resulted in the effective control of M. javanica on okra [53]. In addition, soil amendments with the dry powder of the red alga $M$. afaqhusainii significantly reduced the $M$. javanica penetration in sunflower roots [54] and controlled the M. javanica infestation in okra plants [55]. Finally, soil amendments with dry powdered biomasses from S. swartzii, Spatoglossum asperum, Spatoglossum variabile and $S$. schroederi were repeatedly documented as being effective at 
controlling various root-knot nematodes on tomatoes. They also enhanced plant growth and yield $[27,54,56]$. A key issue for the commercial exploitation of natural nematicidal compounds is represented by the definition of technical formulations as being able to prolong their shelf life and ensure a feasible field application. In this regard, vehiculation by alginates and green silver nanoparticles has been the technical approach most frequently investigated for algal extracts.

Alginate is a polysaccharide extracted from marine brown algae that is generally used as a gelling agent in food and in the pharmaceutical industry, as well as for the formulation of biocontrol agents [57-59]. The main advantages of alginate preparations are the absence of any toxicity and quick degradability in soil. A recent greenhouse study of El Ansary et al. [60] documented a significant reduction of the M. javanica infestation in eggplants following soil treatments with algal alginates from Colpomenia sinuosa, Turbinaria turbinate and C. myrica. This peaked at an almost $80 \%$ reduction in egg formation on eggplant roots. It has been suggested that the ability of alginates to control nematode infection relies on triggering plant defense responses, probably through the salicylic acid signaling pathway [61].

In recent years, nanoparticles such as nanosilvers have been proposed as a new tool for the control of plant pathogens and parasites-including nematodes [62-64]. Under greenhouse conditions, soil treatments with green silver nanoparticles synthesized from the extracts of $U$. lactuca and T. turbinate resulted in a significant reduction in galls, $M$. javanica females, egg-masses on the eggplant root systems and juveniles as well as in a remarkable increase in plant growth [65]. 
Table 1. Seaweeds tested for the control of plant-parasitic nematodes.

\begin{tabular}{|c|c|c|c|c|c|c|c|}
\hline Organism & Nematode & Type of Study & Material & Dose & Inoculum & Host Plant & Reference \\
\hline \multicolumn{8}{|l|}{ Phaeophyta } \\
\hline \multirow{8}{*}{ Ascophyllum nodosum } & M. javanica & In vitro, in vivo $(\mathrm{P})$ & Maxicrop & $3.6 \%$ & $\mathrm{~J} 2$ & Tomato & [43] \\
\hline & M. javanica & In vivo $(\mathrm{P})$ & Maxicrop & $3.6 \%$ & $\mathrm{~J} 2$ & Tomato & [44] \\
\hline & M. javanica & In vivo $(\mathrm{A})$ & Maxicrop & $0.075 \%$ & $\mathrm{~J} 2$ & Arabidopsis & [45] \\
\hline & M. incognita & In vivo $(\mathrm{P})$ & Algaefol & 10-25 mL/Kg soil & eggs & Tomato & [46] \\
\hline & M. javanica & In vivo $(\mathrm{P})$ & extract & $1 \%$ & eggs & Basil & [47] \\
\hline & M. chitwoodi, M. hapla & In vitro, in vivo $(\mathrm{P})$ & OSMO & $5 \mathrm{~mL} / \mathrm{L}$ & $\mathrm{J} 2$ & Tomato & [39] \\
\hline & Radopholus similis & In vivo $(\mathrm{P})$ & pwd extract & $2.24 \mathrm{Kg} / \mathrm{ha}$ & NI & Citrus & [41] \\
\hline & $\begin{array}{l}\text { Belonolaimus } \\
\text { longicaudatus }\end{array}$ & In vivo $(F)$ & Maxicrop, Seaborn & $\begin{array}{l}2.25-4.5-6.75 \mathrm{Kg} / \mathrm{ha} \\
2.47-4.94-7.42 \mathrm{~L} / \mathrm{ha}\end{array}$ & NI & Centipede grass & {$[42]$} \\
\hline \multirow{3}{*}{$\begin{array}{l}\text { Colpomenia sinuosa } \\
\text { Cystoseria indica }\end{array}$} & M. javanica & In vivo $(\mathrm{P})$ & dry alginate & $2.5 \mathrm{~g} / 100 \mathrm{~mL}$ & $\mathrm{~J} 2$ & Eggplant & {$[60]$} \\
\hline & M. javanica & In vitro & & & & & [34] \\
\hline & M. incognita & In vitro & & & & & {$[35,37]$} \\
\hline \multirow[t]{2}{*}{ Cystoseria myrica } & M. incognita & In vivo $(\mathrm{P})$ & dry powder & $20 \mathrm{~g} /$ plant & $\mathrm{J} 2$ & Eggplant & [35] \\
\hline & M. javanica & In vivo $(\mathrm{P})$ & dry alginate & $2.5 \mathrm{~g} / 100 \mathrm{~mL}$ & $\mathrm{~J} 2$ & Eggplant & {$[60]$} \\
\hline \multirow[t]{2}{*}{ Cystoseria trinode } & M. incognita & In vitro, in vivo $(\mathrm{P})$ & dry powder & $20 \mathrm{~g} /$ plant & $\mathrm{J} 2$ & Eggplant & [35] \\
\hline & M. incognita & In vivo $(\mathrm{P})$ & Kelpak 66 & $1: 500 v / v$ & $\mathrm{~J} 2$ & Tomato & [48] \\
\hline \multirow{3}{*}{$\begin{array}{l}\text { Lyengaria stellata, } \\
\text { Jolyna laminarioides, } \\
\text { Padina pavonia }\end{array}$} & M. javanica, & In vitro & & & & & [34] \\
\hline & M. javanica, & In vitro, in vivo $(\mathrm{P})$ & dry powder & $1 \% w / w$ & eggs & Okra, Tomato & [34] \\
\hline & M. incognita & In vitro, in vivo $(\mathrm{P})$ & dry powder & $20 \mathrm{~g} /$ plant & $\mathrm{J} 2$ & Eggplant & [35] \\
\hline \multirow{2}{*}{$\begin{array}{l}\text { Padina tetrastrommatica } \\
\text { Sargassum muticum }\end{array}$} & M. javanica & In vitro & & & & & {$[33,34]$} \\
\hline & M. incognita & In vitro & & & & & [37] \\
\hline \multirow{3}{*}{ Sargassum tenerrimum } & M. javanica & In vitro & & & & & [32-34] \\
\hline & M. javanica & In vivo $(P)$ & dry powder & $0.5-1 \% w / w$ & eggs & Okra & {$[32,34]$} \\
\hline & M. javanica & In vitro & & & & & [32] \\
\hline \multirow[t]{2}{*}{ Sargassum swartzii } & M. javanica & In vivo $(\mathrm{P})$ & dry powder & $1 \% w / w$ & Eggs & Okra & {$[32,34]$} \\
\hline & M. javanica & In vivo $(\mathrm{P})$ & dry powder & $0.5-1 \% w / w$ & Eggs/J2 & Tomato & {$[54,56]$} \\
\hline \multirow{3}{*}{$\begin{array}{l}\text { Sargassum vulgare } \\
\text { Sargassum wigbtii }\end{array}$} & Meloidogyne spp. & In vivo $(\mathrm{P})$ & dry powder & $5 \mathrm{~g} / \mathrm{kg}$ soil & $\mathrm{J} 2$ & Banana & [52] \\
\hline & M. javanica & In vitro & & & & & [32] \\
\hline & M. javanica & In vivo $(\mathrm{P})$ & dry powder & $1 \% w / w$ & eggs & Okra & {$[32,34]$} \\
\hline
\end{tabular}


Table 1. Cont.

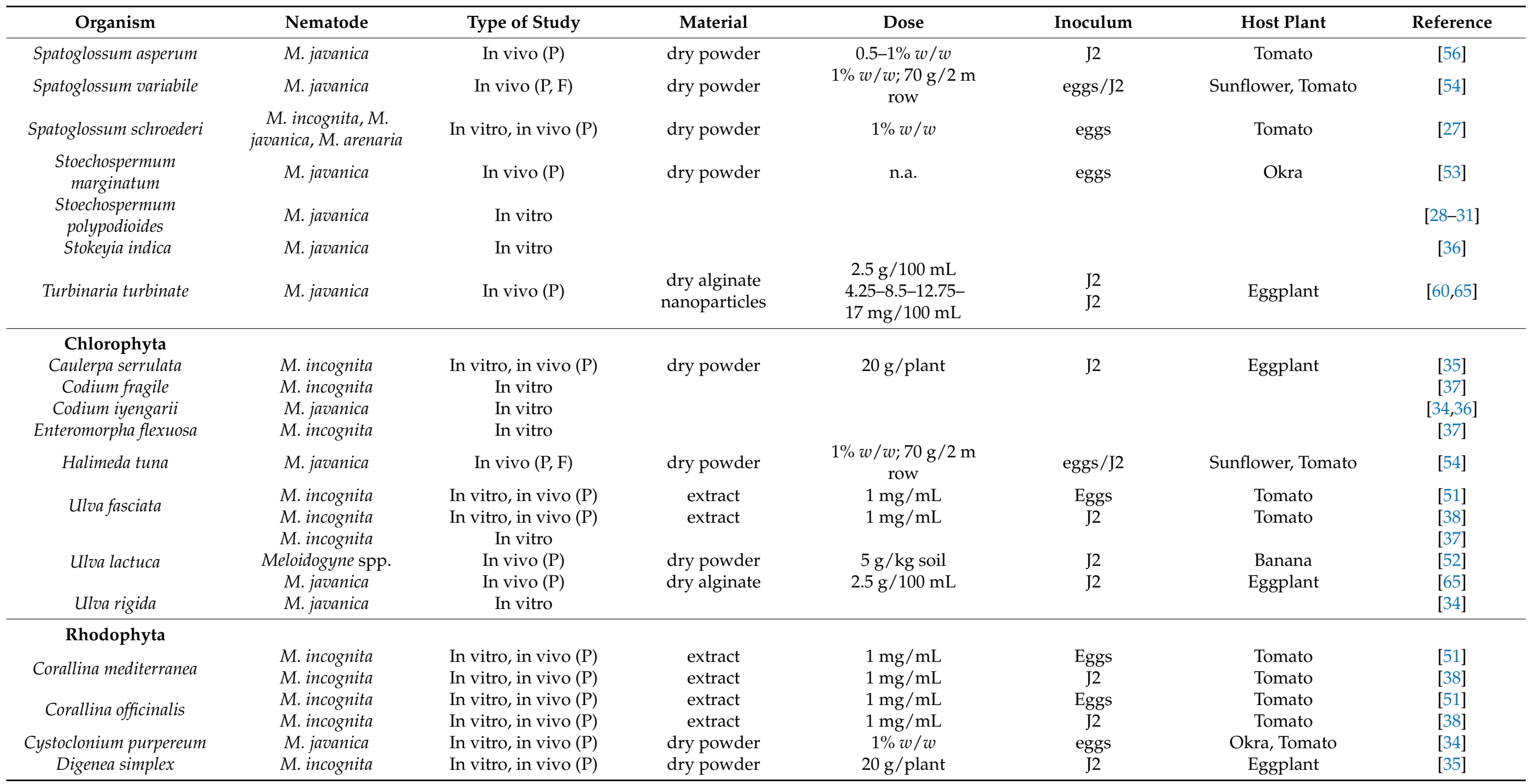


Table 1. Cont.

\begin{tabular}{|c|c|c|c|c|c|c|c|}
\hline Organism & Nematode & Type of Study & Material & Dose & Inoculum & Host Plant & Reference \\
\hline Dilsea carnosa & M. incognita & In vitro & & & & & [37] \\
\hline Hypnea valentiae & M. javanica & In vitro, in vivo $(\mathrm{P})$ & dry powder & $1 \% w / w$ & eggs & Okra, Tomato & [34] \\
\hline Jania capillacea, & M. javanica & In vitro & & & & & {$[36]$} \\
\hline Jania rubens & Meloidogyne spp. & In vivo $(\mathrm{P})$ & dry powder & $5 \mathrm{~g} / \mathrm{Kg}$ soil & $\mathrm{J} 2$ & Banana & [52] \\
\hline Laurencia nidifica & M. incognita & In vitro & & & & & {$[37]$} \\
\hline Laurencia obtuse & Meloidogyne spp. & In vivo $(\mathrm{P})$ & dry powder & $5 \mathrm{~g} / \mathrm{Kg}$ soil & $\mathrm{J} 2$ & Banana & [52] \\
\hline \multirow{2}{*}{$\begin{array}{l}\text { Melanothamnus } \\
\text { afaqhusainii }\end{array}$} & M. javanica & In vitro & & & & & {$[33,34]$} \\
\hline & M. javanica & In vivo $(\mathrm{P}, \mathrm{F})$ & dry powder & $\begin{array}{c}1 \% w / w ; 70 \mathrm{~g} / 2 \mathrm{~m} \\
\text { row }\end{array}$ & eggs/J2 & Sunflower, Tomato & [54] \\
\hline & M. javanica & In vivo $(\mathrm{P})$ & dry powder & $0.25-0.5-1 \% w / w$ & eggs & Okra & [55] \\
\hline Solieria robusta & M. javanica & In vitro & & & & & [36] \\
\hline
\end{tabular}

$\mathrm{P}=$ pots $; \mathrm{F}=$ field $; \mathrm{A}=$ agar plates; $\mathrm{NI}=$ natural infested soil pwd extract $=$ powdered extract. 


\section{Cyanobacteria}

Cyanobacteria are prokaryotic oxygenic phototrophs that are found in almost every habitat on earth. Among the five divisions of Cyanobacteria, Cyanophyta (blue-green algae) and Pyrrophyta (dinoflagellates) are rich sources of novel compounds and have been extensively investigated $[19,66]$.

Several studies have unraveled the nematicidal potential of blue-green algae from fresh water and soil species [67]. Pioneer investigations documented an increased plantparasitic nematode mortality and/or hatching inhibition following the inoculation of soil with endospores [68,69] or extracts and exudes [70,71] from cyanobacteria. Moreover, root-knot nematode egg masses and galls were also reduced by the incorporation into soil of blue-green algae [72-75].

Fresh water blue-green algae species exhibit an easier cultivability in comparison with marine organisms. However, the advancement in cultivation technologies and in molecular biology techniques has raised a renewed interest in exploring the marine habitat for new drugs. Marine forms of cyanobacteria are rich sources of metabolites and toxins, which are potentially novel bioactive compounds with wide pharmaceutical applications, especially towards the treatment of many human diseases. The marine cyanobacteria Lyngbya spp. are, to date the most productive source of bioactive cyanobacterial compounds [76] and show potent anti-oxidant, anti-inflammatory, anti-diabetic and anti-cancer activity [19,77]. In particular, lipopeptides isolated from the cyanobacterium Lyngbia majuscula have shown a spectrum of biological activities consistent with their functioning as defense metabolites, including sodium channel blocking activity and arthropod and fish toxicity $[78,79]$. The nematicidal potential of these compounds is almost completely uninvestigated as, to the best of our knowledge, only one assay of the activity of a Microcoleus lyngbyaceus extract against $M$. incognita has been performed; however, it resulted ineffective at the applied concentrations [27].

\section{Sponges}

Sponges are an important source of biologically active natural products [80]. However, sponges are often associated with symbiotic microbial populations such as: archaea, bacteria, actinomycetes, fungi, cyanobacteria and microalgae, which represent the probable source of bioactive metabolites [81]. The strain BCPBMS-1 of Pseudomonas fluorescens, isolated from the marine sponge Callyspongia diffusa, showed nematicidal activity against M. javanica both in vitro and in pot experiments [82].

To the best of our knowledge, no other studies have been carried out to unravel the biocontrol potential of sponges or their associated microorganisms against PPN, though several products isolated from marine sponges [80] demonstrated an anthelmintic activity against Haemonchus contortus, a socioeconomically important parasitic nematode of livestock animals (Table 2). Amphilactams A-D, isolated from an Amphimedon sp. sponge, inhibited $H$. contortus larval development but had poor or nil activity against nematode eggs [83]. A strong inhibition of larval development of the same nematode was also reported for: polyketides geodin A, isolated from the sponge Geodia sp. [84], onnamide F (2), isolated from the marine sponge Trachycladus laevispirulifer [85] and the 6-N-acyladenine phorioadenine A, which was detected in the crude extract from the Phoriospongia sp. (CMB03107) [86]. Finally, a moderate to limited inhibition of $H$. contortus motility was recently documented for fromiamycalin, a pentacyclic guanidine alkaloid, and halaminol A, an acetamide that were isolated from the extracts of the demosponges Monanchora unguilata and Haliclona sp., respectively [87]. 
Table 2. Anthelmintic marine natural products from sponges.

\begin{tabular}{|c|c|c|c|c|c|c|}
\hline Compound & Type & Source & Nematode & Toxicity & Country & Reference \\
\hline $\begin{array}{l}\text { Amphilactans } \\
\text { A-D }\end{array}$ & macrolide & Amphimedon sp. & H. contortus & $\mathrm{LD}_{99}$ 0.30-7.5 $\mu \mathrm{g} / \mathrm{mL}$ & AUS & [83] \\
\hline Geodin A & macrolide & Geodia & H. contortus & $\mathrm{LD}_{99} 1 \mu \mathrm{g} / \mathrm{mL}$ & AUS & [84] \\
\hline Onnamide F (2) & polyketide & $\begin{array}{l}\text { Trachicladus } \\
\text { laevispirulifer }\end{array}$ & H. contortus & $\mathrm{LD}_{99} 2.6 \mu \mathrm{g} / \mathrm{mL}$ & AUS & [85] \\
\hline $\begin{array}{l}\text { Thiocyanatins } \\
\text { (1-4) }\end{array}$ & polyketide & Oceanapia sp. & H. contortus & $\mathrm{LD}_{99} 3.1-8.3 \mu \mathrm{g} / \mathrm{mL}$ & AUS & [88] \\
\hline $\begin{array}{c}(-)- \\
\text { echinobetaine } \\
A(1)\end{array}$ & alkaloid & $\begin{array}{l}\text { Echinodyctium } \\
\text { sp. }\end{array}$ & H. contortus & $\mathrm{LD}_{99} 83 \mu \mathrm{g} / \mathrm{mL}$ & AUS & [89] \\
\hline $\begin{array}{c}(+)- \\
\text { echinobetaine } \\
B(2)\end{array}$ & alkaloid & $\begin{array}{c}\text { Echinodyctium } \\
\text { sp. }\end{array}$ & H. contortus & $\mathrm{LD}_{99} 8.3 \mu \mathrm{g} / \mathrm{mL}$ & AUS & [90] \\
\hline Phorioadenine A & alkaloid & $\begin{array}{c}\text { Phoriospongia } \\
\text { sp. }\end{array}$ & H. contortus & $\mathrm{LD}_{99} 31 \mu \mathrm{g} / \mathrm{mL}$ & AUS & [86] \\
\hline Fromiamycalin & alkaloid & $\begin{array}{c}\text { Monanchora } \\
\text { unguiculata }\end{array}$ & H. contortus & $\begin{array}{c}\text { L4 development } \mathrm{IC}_{50} \\
26.6 \mu \mathrm{M} ; \\
\text { L4 motility } \\
\mathrm{IC}_{50} 39.4 \mu \mathrm{M}\end{array}$ & AUS & [87] \\
\hline Halaminol A & alkaloid & Haliclona sp. & H. contortus & $\begin{array}{c}\text { L4 development } \mathrm{IC}_{50} \\
500 \mu \mathrm{M} ; \\
\text { L4 motility } \\
\mathrm{IC}_{50} 100 \mu \mathrm{M}\end{array}$ & AUS & [87] \\
\hline
\end{tabular}

\section{Conclusions}

Literature reports indicate that marine organisms such as seaweeds, cyanobacteria and sponges can be a huge source of new nematicidal products. Seaweeds seem to offer the highest potential of exploitation. They have largely proved to have a high effectiveness for relevant phytonematode species, as well as for plant bio-stimulating effects. Information about the mechanisms of nematicidal activity and the plant growth-promoting effects of seaweeds is almost nil. This shows that more in-depth studies are required to elucidate their role in direct nematode control and plant resistance to nematode attack. Phenotyping of various seaweed extracts could be a useful tool to assess their bioactive components, application rates, timing and genetic variation in plant responses. Cyanobacteria and sponges also represent promising raw materials for new nematicides, though further study is required. The keystone for the industrialization of these products and of most natural nematicides, would be the development of innovative formulations such as micro or nanoencapsulation in order to preserve product bioactivity and ensure technical feasibility.

As plant-derived compounds and biocontrol agents, marine-product-derived nematicides represent a helpful tool for nematode management in organic systems. However, use on conventional crops should be limited to low nematode infestations or in combination with synthetic nematicides.

Author Contributions: P.V. and M.T.M. conceptualization, collecting of data and writing the original draft. All authors have read and agreed to the published version of the manuscript.

Funding: This research received no external funding.

Institutional Review Board Statement: Not applicable.

Informed Consent Statement: Not applicable.

Data Availability Statement: Not applicable.

Conflicts of Interest: The authors declare no conflict of interest. 


\section{References}

1. Nicol, J.M.; Turner, S.J.; Coyne, D.L.; den Nijs, L.; Hockland, S.; Tahna maafi, Z. Current nematode threats to world agriculture. In Genomics and Molecular Genetics of Plant-Nematode Interactions; Jones, J., Gheysen, G., Fenoll, C., Eds.; Springer: Dordrecht, The Netherlands, 2011; pp. 21-43.

2. Chitwood, D.J. Research on plant-parasitic nematode biology conducted by the United States Department of AgricultureAgricultural Research Service. Pest Manag. Sci. 2003, 59, 748-753. [CrossRef]

3. Bird, D.M.K.; Kaloshian, I. Are roots special? Nematodes have their say. Physiol. Mol. Plant Pathol. 2003, 62, 115-123. [CrossRef]

4. Jones, J.T.; Haegeman, A.; Danchin, E.G.J.; Gaur, H.S.; Helder, J.; Jones, M.G.K.; Kikuchi, T.; Manzanilla-Lopez, R.; Palomares-Rius, J.E.; Wesemael, W.M.L.; et al. Top 10 plant-parasitic nematodes in molecular plant pathology. Mol. Plant Pathol. $2013,14,946-961$. [CrossRef] [PubMed]

5. Wesemael, W.M.L.; Viaene, N.; Moens, M. Root-knot nematodes (Meloidogyne spp.) in Europe. Nematology 2011, 13, 3-16. [CrossRef]

6. Somasekhar, N.; Prasad, J.S. Plant-nematode interactions: Consequences of climate change. In Crop Stress and Its Management: Perspectives and Strategies; Venkateswarlu, B., Shanker, A.K., Shanker, C., Maheswari, M., Eds.; Springer: Dordrecht, The Netherlands, 2011; pp. 547-564.

7. Eastburn, D.M.; McElrone, A.J.; Bilgin, D.D. Influence of atmospheric and climatic change on plat-pathogen interactions. Plant Pathol. 2011, 60, 54-69. [CrossRef]

8. Collange, B.; Navarrete, M.; Peyre, G.; Mateille, T.; Tchamitchian, M. Root-knot nematode (Meloidogyne) management in vegetable crop production: The challenge of an agronomic system analysis. Crop Prot. 2011, 30, 1251-1262. [CrossRef]

9. Abawi, G.S.; Widmer, T.L. Impact of soil health management practices on soilborne pathogens, nematodes and root diseases of vegetable crops. Appl. Soil Ecol. 2000, 15, 37-47. [CrossRef]

10. Forghani, F.; Hajihassani, A. Recent advances in the development of environmentally benign treatments to control root-knot nematodes. Front. Plant Sci. 2020, 11, 1125. [CrossRef]

11. Rosskopf, E.; Di Gioia, F.; Hong, J.C.; Pisani, C.; Kokalis-Burelle, N. Organic amendments for pathogen and nematode control. Ann. Rev. Phytopathol. 2020, 58, 277-311. [CrossRef]

12. Tariq, M.; Khan, A.; Asif, M.; Khan, F.; Ansari, T.; Shariq, M.; Siddiqui, M.A. Biological control: A sustainable and practical approach for plant disease management. Acta Agric. Scand. Sect. B Soil Plant Sci. 2020, 70, 507-524. [CrossRef]

13. Chitwood, D. Phytochemical based strategies for nematode control. Annu. Rev. Phytopathol. 2002, 40, 221-249. [CrossRef]

14. Chatzipavlidis, I.; Kefalogianni, I.; Venieraki, A.; Holzapfel, W. Status and trend of the conservation and susteinable use of microorganisms in agroindustrial processes. In Commission of Genetic Resources for Food and Agriculture; FAO Background study paper no. 64; FAO: Rome, Italy, 2013.

15. Ntalli, N.G.; Caboni, P. Botanical nematicides: A review. J. Agric. Food Chem. 2012, 60, 9929-9940. [CrossRef] [PubMed]

16. Avato, P.; D'Addabbo, T.; Leonetti, P.; Argentieri, M.P. Nematicidal potential of Brassicaceae. Phytochem. Rev. 2013, 12, 791-802. [CrossRef]

17. D’Addabbo, T.; Argentieri, M.P.; Żuchowski, J.; Biazzi, E.; Tava, A.; Oleszek, W.; Avato, P. Activity of saponins from medicago species against phytoparasitic nematodes. Plants 2020, 9, 443. [CrossRef] [PubMed]

18. Donia, M.; Hamann, M.T. Marine natural products and their potential application as anti-infective agents. Lancet Infect. Dis. 2003, 3, 338-348. [CrossRef]

19. Jha, R.K.; Zi-rong, X. Biomedical compounds from marine organisms. Mar. Drugs 2004, 2, 123-146. [CrossRef]

20. Romano, G.; Costantini, M.; Sansone, C.; Lauritano, C.; Ruocco, N.; Ianora, A. Marine microorganisms as a promising and sustainable source of bioactive molecules. Mar. Environ. Res. 2017, 128, 58-69. [CrossRef]

21. Yassen, A.A.; Badran, N.M.; Zaghloul, S.M. Role of some organic residues as tools for reducing metals hazard in plant. World J. Agric. Sci. 2007, 3, 204-209.

22. Jolivet, E.; De Langlais-Jeannin, I.; Morot-Gaudry, J.F. Extracts of marine algae: Phyto-active properties and agronomic value. Annee Biol. 1991, 30, 109-126.

23. Craigie, J.S. Seaweed extracts stimuli in plant science and agriculture. J. App. Phycol. 2011, 23, 371-393. [CrossRef]

24. Khan, W.; Rayirath, U.P.; Subramanian, S.; Jithesh, M.N.; Rayorath, P.; Hodges, D.M.; Critchley, A.T.; Craigie, J.S.; Norrie, J.; Prithiviraj, B. Seaweed extracts as biostimulants of plant growth and development. J. Plant Growth Regul. 2009, 27, 270-279. [CrossRef]

25. Santaniello, A.; Scartazza, A.; Gresta, F.; Loreti, E.; Biasone, A.; Di Tommaso, D.; Piaggesi, A.; Perata, P. Ascophyllum nodosum seaweed extract alleviates drought stress in Arabidopsis by affecting photosynthetic performance and related gene expression. Front. Plant Sci. 2017, 8, 1362. [CrossRef]

26. Xiong, J.; Zhou, Q.; Luo, H.; Xia, L.; Sun, M.; Yu, Z. Systemic nematicidal activity and biocontrol efficacy of Bacillus firmus against the root-knot nematode Meloidogyne incognita. World J. Microbiol. Biotechnol. 2015, 31, 661-667. [CrossRef]

27. Paracer, S.M.; Tarjan, A.C.; Hodgson, L.M. Effective use of marine algal products in the management of plant parasitic nematodes. J. Nematol. 1987, 19, 194-200.

28. Abid, M.; Zaki, M.J.; Maqbool, M.A. Use of brown algae, Stoechospermum marginatum for the control of root-knot nematode in brinjal. Mar. Res. 1993, 2, 39-44. 
29. Sultana, V.; Ehteshamul-Haque, S.; Ara, J.; Ahmad, V.U. Utilization of seaweeds for the control of root diseases of tomato. In Proceedings of the National ONR Symposium on Arabian Sea as a Resource of Biological Diversity; Ahmad, V.U., Ed.; HEJRes Chem, University of Karachi: Karachi, Pakistan, 2000; pp. 193-206.

30. Rizvi, M.A.; Shameel, M. In vitro nematicidal activities of seaweed extracts from Karachi coast. Pak. J. Bot. 2006, 38, 1245-1248.

31. Karthick, N.; Prasanth Kumar, V.; Umamaheswari, S. In vitro nematicidal activity of different seaweed extracts against Meleoidogyne javanica (Tylenchida: Heteroderidae). Int. J. Develop. Res. 2014, 4, 1841-1843.

32. Ara, J.; Ehteshamul-Haque, S.; Sultana, V.; Ghaffar, A.; Qasim, R. Use of Sargassum species for the control of Meloidogyne javanica in okra. Nematol. Medit. 1997, 25, 125-128.

33. Khan, A.S.; Abid, M.; Hussain, F. Nematicidal activity of seaweeds against Meloidogyne javanica. Pak. J. Nematol. 2015, 33, 195-203.

34. Abid, M.; Zaki, M.J.; Khan, M.Q.; Sattar, A. Use of marine algae for the management of root-knot nematode (Meloidogyne javanica) in okra and tomato plants. Int. J. Phycol. Phycochem. 2005, 1, 187-192.

35. Afia, A.I.; El-Nuby, A.S.M. Seaweeds as a managing approach for root-knot nematode disease. Egypt. J. Agronematol. 2016, 15, 95-108.

36. Sultana, V.; Ara, J.; Ehteshamul-Haque, S. Suppression of root rotting fungi and root knot nematode of chili by seaweed and Pseudomonas aeruginosa. J. Phytopathol. 2008, 156, 390-395. [CrossRef]

37. Nour El-Deen, A.H.; Issa, A.A. Nematicidal properties of some algal aqueous extracts against root-knot nematode, Meloidogyne incognita in vitro. Egypt. J. Agron. 2016, 15, 67-78. [CrossRef]

38. Ghareeb, R.Y.; Adss, I.A.; Bayoumi, S.R.; El-Habashy, D.E. The nematicidal potentiality of some algal extracts and their role in enhancement the tomato defense genes against root knot-nematodes. Egypt. J. Biol. Pest Contr. 2019, 29, 53-63. [CrossRef]

39. Ngala, M.B.; Valdes, Y.; dos Santos, G.; Perry, R.N.; Wesemael, W.M.L. Seaweed-based products from Ecklonia maxima and Ascophyllum nodosum as control agents for the root-knot nematodes Meloidogyne chitwoodi and Meloidogyne hapla on tomato plants. J. Appl. Phycol. 2016, 28, 2073-2082. [CrossRef]

40. Perry, R.N. Plant signals in nematode hatching and attraction. In Molecular Aspects of Plant Nematode Interactions; Fenoll, C., Grundler, M.W., Ohl, S.A., Eds.; Kluwer Academic Publishers: Dortrecht, The Netherlands, 1997; pp. 38-50.

41. Tarjan, A.C. Kelp derivatives for nematode-infected citrus trees. J. Nematol. 1977, 9, 287.

42. Morgan, K.T.; Tarjan, A.C. Management of sting nematode on centipede grass with kelp extracts. Proc. Fla. State Hort. Soc. 1980, 93, 97-99.

43. Whapham, C.A.; Jenkins, T.; Blunden, G.; Hankins, S.D. The role of seaweed extracts Ascophyllum nodosum, in the reduction in fecundity of Meloidogyne javanica. Fund. Appl. Nematol. 1994, 17, 181-183.

44. Wu, Y.; Jenkins, T.; Blunden, G.; Whapham, C.; Hankins, S.D. The role of betains in alkaline extracts of Ascophyllum nodosum in reduction of Meloidogyne javanica and M. incognita infestations of tomato plants. Fund. Appl. Nematol. 1997, 20, 99-102.

45. Wu, Y.; Jenkins, T.; Blunden, G.; von Mende, N.; Hankins, S.D. Suppression of fecundity of the root-knot nematode, Meloidogyne javanica, in monoxenic cultures of Arabidopsis thaliana treated with an alkaline extract of Ascophyllum nodosum. J. Appl. Phycol. 1998, 10, 91-94. [CrossRef]

46. Radwan, M.A.; Farrag, S.A.A.; Abu-Elamayem, M.M.; Ahmed, N.S. Biological control of the root-knot nematode, Meloidogyne incognita on tomato using bioproducts of microbial origin. Appl. Soil Ecol. 2012, 56, 58-62. [CrossRef]

47. Nour El-Deen, A.H.; Abdel-Kafie, O.M.; El-Ghareb, N.M. Evaluation of seaweed extract and various plant products against Meloidogyne incognita on basil. G. Agric. 2013, 16, 29-34.

48. Featonby-Smith, B.C.; Van Staden, J. The effect of seaweed concentrate on the growth of tomatoes in nematode infested soil. Sci. Hort. 1983, 20, 137-146. [CrossRef]

49. Dropkin, V.H.; Helgeson, J.P.; Upper, C.D. The hypersensitivity reaction of tomatoes resistant to Meloidogyne incognita reversal by cytokinins. J. Nematol. 1969, 1, 55-61.

50. Crouch, I.J.; van Staden, J. Evidence for the presence of plant growth regulators in commercial seaweed products. Plant Growth Regul. 1993, 13, 21-29. [CrossRef]

51. Abdel Rasoul, M.A. Biopotentials of marine algae extracts against root-knot nematode, Meloidogyne incognita. J. Plant Prot. Pathol. 2017, 8, 165-171. [CrossRef]

52. El-Ansary, M.S.M.; Hamouda, R.A. Biocontrol of root-knot nematode infected banana plants by some marine algae. Russ. J. Mar. Biol. 2014, 40, 140-146. [CrossRef]

53. Ehteshamul-Haque, S.; Abid, M.; Sultana, V.; Ara, J.; Ghaffar, A. Use of organic amendments on the efficacy of biocontrol agents in the control of root rot and root knot disease complex of okra. Nematol. Medit. 1996, 24, 13-16.

54. Sultana, V.; Baloch, G.N.; Ara, J.; Ehteshamul-Haque, S.; Tariq, R.M.; Athar, M. Seaweeds as alternative to chemical pesticides for the management of root diseases of sunflower and tomato. J. Appl. Bot. Food Qual. 2011, 84, 162-168.

55. Khan, A.M.; Naz, S.; Abid, M. Evaluation of marine red alga Melanothamnus afaqhusainii against Meloidogyne incognita, fungus and as fertilizing potential on okra. Pak. J. Nematol. 2016, 34, 91-100.

56. Sultana, V.; Ehteshamul-Haque, S.; Ara, J.; Athar, M. Effect of brown seaweeds and pesticides on root rotting fungi and root-knot nematode infecting tomato roots. J. Appl. Bot. Food Qual. 2009, 83, 50-53.

57. Papavizas, G.C.; Lewis, J.A. Effect of Gliocladius and Trichoderma on damping off and blight of snap bean caused by Sclerotium rolfesii. Plant Pathol. 1989, 38, 277-286. [CrossRef] 
58. Yang, L.; Paulson, A.T. Effects of lipids on mechanical and moisture barrier properties of edible gelling film. Food Res. Int. 2000, 33, 571-578. [CrossRef]

59. Goh, C.H.; Heng, P.W.S.; Chan, L.W. Alginate as a useful natural polymer for microencapsulation and therapeutic applications. Carbohyd. Polym. 2012, 88, 1-12. [CrossRef]

60. El-Ansary, M.S.M.; Hamouda, R.A.; Eldemery, S.M.M. New approaches for controlling the root-knot nematode, Meloidogyne javanica by alginate and its effect on eggplant DNA pattern. Egypt. J. Biol. Pest Contr. 2017, 27, 155-163.

61. Laporte, D.; Vera, J.; Chandía, N.P.; Zúñiga, E.A.; Matsuhiro, B.; Moenne, A. Structurally unrelated algal oligosaccharides differentially stimulate growth and defense against tobacco mosaic virus in tobacco plants. J. Appl. Phycol. 2007, 19, 79-88. [CrossRef]

62. Roh, J.Y.; Sim, S.J.; Yi, J.; Park, K.; Chung, K.H.; Ryu, D.Y.; Choi, J. Ecotoxicity of silver nanoparticles on the soil nematode Caenorhabditis elegans using functional ecotoxicogenomics. Environ. Sci. Technol. 2009, 43, 3933-3940. [CrossRef]

63. Cromwell, W.A.; Joopil, Y.J.; Young-Ki, J. Nematicidal effects of silver nanoparticles on root-knot nematode in bermudagrass. J. Nematol. 2014, 46, 261-266.

64. Jo, Y.; Starr, J.L.; Deng, Y. Use of silver Nanoparticles for nematode control in the bermudagrass putting green. Turfgrass Environ. Res. Online 2014, 13, 16-18.

65. Abdellatif, K.F.; Hamouda, R.A.; El-Ansary, M.S.M. Green nanoparticles engineering on root-knot nematode infecting eggplants and their effect on plant DNA modification. Iran J. Biotechnol. 2016, 14, 250-259. [CrossRef]

66. Shimizu, Y. Microalgal metabolites. Curr. Opin. Microbiol. 2003, 6, 236-243. [CrossRef]

67. Holajjer, P.; Kamra, A.; Gaur, H.S.; Manjunath, M. Potential of cyanobacteria for biorational management of plant parasitic nematodes: A review. Crop Protect. 2013, 53, 147-151. [CrossRef]

68. Kumar, A.C.; Dhanam, M.; Sowjanya. Pathogenity of Microcoleus spp. (Oscillatoriaceae), to plant and soil nematodes. Indian J. Nematol. 1993, 23, 8-9.

69. Dhanam, M.; Kumar, A.C.; Sowjanya. Microcoleus vaginatus (Oscillatoriaceae), a blue-green alga (or Cyanobacterium) parasitising plant and soil nematodes. Indian J. Nematol. 1994, 24, 125-132.

70. Gaur, H.S. Studies on the hatch inhibition and nematicidal action of exudates and extracts of two cyanobacteria and a green alga. Ann. Plant Prot. Sci. 1995, 32, 158-163.

71. Sharma, H.K.; Gaur, H.S.; Singh, D.V.; Dahar, D.W. Bionematicidal potential of ten species of cyanobacteria against root-knot nematode, Meloidogyne incognita. Int. J. Nematol. 2007, 17, 35-40.

72. Youssef, M.M.A.; Ali, M.S. Management of Meloidogyne incognita infecting cowpea by using some native blue green algae. Anz. Schädlingskde Pflanzenschutz Umweltschutz 1998, 71, 15-16. [CrossRef]

73. Khan, Z.; Park, S.D. Effects of inoculum level and time of Microcoleus vaginatus on control of Meloidogyne incognita on tomato. J. Asia-Pac. Entomol. 1999, 2, 93-96. [CrossRef]

74. Sharma, H.S. Studies on the Bionematicidal Potential of Terrestrial Cyanobacteria for Eco-Friendly Management of the Plant Parasitic Nematode, Meloidogyne Incognita. Ph.D. Thesis, IARI, New Delhi, India, 2004.

75. Khan, Z.; Park, S.D.; Shin, S.Y.; BaeI, S.G.; Yeon, K.; Seo, Y.J. Management of Meloidogyne incognita on tomato by root-dip treatment in culture filtrate of the blue-green alga, Microcoleus vaginatus. Bioresour. Technol. 2005, 96, 1338-1341. [CrossRef]

76. Demay, J.; Bernard, C.; Reinhardt, A.; Marie, B. Natural products from cyanobacteria: Focus on beneficial activities. Mar. Drugs 2019, 17, 320. [CrossRef]

77. Kumar, R.S.; Shakambari, G.; Ashokkumar, B.; Varalakshmi, P. Inhibition of advanced glycation end products formation and inflammation in C. elegans: Studies of potential of Lyngbya sp. against expression of stress related genes and Live cell imaging. Biocatal. Agric. Biotechnol. 2019, 17, 233-241. [CrossRef]

78. Edwards, D.J.; Marquez, B.L.; Nogle, L.M.; McPhail, K.; Goeger, D.E.; Roberts, M.A.; Gerwick, W.H. Structure and biosynthesis of the Jamaicamides, new mixed polyketide-peptide neurotoxins from the marine cyanobacterium Lyngbya maiuscula. Chem. Biol. 2004, 11, 817-833. [CrossRef] [PubMed]

79. Wu, M.; Okino, T.; Nogle, L.M.; Marquez, B.L.; Williamson, R.T.; Sitachitta, N.; Berman, F.W.; Murray, T.F.; McGough, K.; Jacobs, R.; et al. Structure, synthesis, and biological properties of kalkitoxin, a novel neurotoxin from the marine cyanobacterium Lyngbya maiuscula. J. Am. Chem. Soc. 2000, 122, 12041-12042. [CrossRef]

80. Capon, R.J. Marine bioprospecting-Trawling for treasure and pleasure. Eur. J. Org. Chem. 2001, 2001, 633-645. [CrossRef]

81. Belarbi, E.H.; Gomez, A.C.; Chisti, Y. Producing drugs from marine sponges. Biotechnol. Adv. 2003, 21, 585-598. [CrossRef]

82. Vasanthabharathi, V.; Jayalakshmi, S. Nematicidal activity of marine sponge Callyspongia diffusa associated Pseudomonas fluorescens BCPBMS-1. South Indian J. Biol. Sci. 2015, 1, 134-140. [CrossRef]

83. Ovenden, S.P.B.; Capon, R.J.; Lacey, E.; Gill, J.H.; Friedel, T.; Wadsworth, D. Amphilactans A-D: Novel nematocides from Southern Australian marine sponges of the genus Amphimedon. J. Org. Chem. 1999, 64, 1140-1144. [CrossRef]

84. Capon, R.J.; Skene, C.; Lacey, E.; Gill, J.H.; Wadsworth, D.; Frriedel, T. Geodin A magnesium salt: A novel nematocide from a southern Lyngbya sp marine sponge, Geodia. J. Nat. Prod. 1999, 62, 1256-1259. [CrossRef]

85. Vuong, D.; Capon, R.J.; Lacey, E.; Gill, J.H.; Heiland, K.; Friedel, T. Onnamide F: A new nematocide from a southern Australian marine sponge, Trachycladus laevispirulifer. J. Nat. Prod. 2001, 64, 640-642. [CrossRef] 
86. Farrugia, M.; Trotter, N.; Vijayasarathy, S.; Salim, A.A.; Khalil, Z.G.; Lacey, E.; Capon, R.J. Isolation and synthesis of N-acyladenine and adenosine alkaloids from a southern Australian marine sponge, Phoriospongia sp. Tetrahedron Lett. 2014, 55, 5902-5904. [CrossRef]

87. Herath Dilrukshi, H.M.P.; Preston, S.; Abdul, J.; Garcia-Bustos, J.; Taki, A.C.; Addison, R.S.; Hayes, S.; Beattie, K.D.; McGee, S.L.; Martin, S.D.; et al. Identification of Fromiamycalin and Halaminol A from Australian marine sponge extracts with anthelmintic activity against Haemonchus contortus. Mar. Drugs 2019, 17, 598. [CrossRef] [PubMed]

88. Capon, R.J.; Skene, C.; Liu, E.H.; Lacey, E.; Gill, J.H.; Heiland, K.; Friedel, T. Nematocidal thiocyanatins from a southern Australian marine sponge Oceanapia sp. J. Nat. Prod. 2004, 67, 1277-1282. [CrossRef]

89. Capon, R.J.; Vuong, D.; Lacey, E.; Gill, J.H. (-)-Echinobetaine A: Isolation, structure elucidation, synthesis, and SAR studies on a new nematocide from a Southern Australian marine sponge, Echinodictyum sp. J. Nat. Prod. 2005, 68, 179-182. [CrossRef] [PubMed]

90. Capon, R.J.; Vuong, D.; McNally, M.; Peterle, T.; Trotter, N.; Lacey, E.; Gill, J.H. (+)-Echinobetaine B: Isolation, structure elucidation, synthesis and preliminary SAR studies on a new nematocidal betaine from a southern Australian marine sponge, Echinodictyum sp. Org. Biomol. Chem. 2005, 3, 118-122. [CrossRef] [PubMed] 